\title{
A epistemologia da enfermagem psiquiátrica e saúde mental: a necessidade de construção de competências na formação do enfermeiro
}

\author{
Roselma Lucchese ${ }^{1}$, Sônia Barros²
}

\footnotetext{
1 Enfermeira, professor M III, do curso de Enfermagem da Fundação Educacional de Fernandópolis. Mestre em Enfermagem Psiquiátrica pela Escola de Enfermagem da USP (EEUSP). Doutoranda do Programa Interunidades da EEUSP roselma@acif.com.br

2 Enfermeira.Professor Doutor do Departamento de Enfermagem Psiquiátrica da EEUSP. sobarros@usp.br
}

\section{NOTA PRÉVIA}

Trata-se de um estudo para elaboração de tese de doutorado que elegeu como tema o ensino de enfermagem em psiquiatria e saúde mental, focalizando a educação para a mudança. A formação de enfermeiro exige do educador, cada vez mais, reflexão crítica sobre sua prática, num movimento dinâmico e dialético entre o fazer e o pensar sobre esse fazer. Acreditando nesta afirmativa, repensamos a epistemologia da enfermagem psiquiátrica e saúde mental sob um novo foco da educação, que está direcionado para a aquisição de habilidades no campo afetivo, cognitivo e psicomotor e para a mobilização do conhecimento diante de situação real. Ambos os focos, ao mesmo tempo, irão constituir a competência do profissional. No estudo que pretendemos desenvolver teremos como recorte a reprodução do conhecimento de enfermagem psiquiátrica/saúde mental, interessando-nos as situações de sua efetiva aplicação. Para tanto buscamos em Perrenoud (1999) a definição de competência como a capacidade de agir eficientemente em uma situação real, apoiada em conhecimentos, mas sem limitar-se a eles. Para enfrentar ou solucionar determinadas situações com pertinência e eficácia mobiliza-se vários recursos cognitivos, como saberes, capacidades, informações e outros. Tal conceito de competência pode indicar um caminho para reverter a atual situação do ensino nesta área, que por várias razões, explicitam uma dicotomia entre o saber reproduzido nas escolas e o praticado na assistência ao doente mental, resultando na formação de profissionais acríticos e pouco atuantes politicamente. Formulamos como objetivos para a pesquisa: identificar a representação sobre competência junto aos sujeitos da pesquisa (docentes e enfermeiros de campo); analisar os conhecimentos necessários e as habilidades que devem ser desenvolvidas pelo enfermeiro para a construção das competências de intervenção no processo saúde-doença, para o ensino da prática de enfermagem psiquiátrica e saúde mental; identificar limites e possibilidades para a construção de competências a partir das representações dos sujeitos trabalhadas nos grupos focais e do referencial teórico "pedagogia das competências". É uma pesquisa de abordagem qualitativa, cujo referencial metodológico seguirá a dialética marxista para a investigação do objeto e, como balizas para o conhecimento do mesmo, utilizaremos as categorias analíticas Práxis e Relações sociais de produção. Serão sujeitos, docentes da EEUSP e enfermeiros dos campos práticos utilizados pela mesma escola.

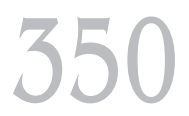

